\title{
ADAPTASI KEBIASAAN BARU DAN MASALAH PSIKOSOSIAL AKIBAT PANDEMI COVID-19 PADA SISWI ANGGOTA PMR SMAN 1 SUMBERPUCUNG MALANG
}

\author{
Mochamad Ali Sodikin ${ }^{1}$, Berliany Venny Sipollo ${ }^{2}$ \\ ${ }^{1}$ RS Jiwa Dr. Radjiman Wediodiningrat Lawang \\ Email: alisodikin2410@gmail.com \\ ${ }^{2}$ Program Studi Keperawatan, STIKes Panti Waluya Malang \\ Email: berlianyvenny@,rocketmail.com
}

\begin{abstract}
ABSTRAK
Coronavirus Diseases 2019 (COVID-19) tidak hanya berdampak pada kondisi fisik seseorang, tetapi juga menimbulkan dampak secara psikologis. Angka kejadian COVID-19 masih terus meningkat dan diiringi dengan angka kesembuhan yang juga semakin meningkat, kondisi tersebut tidak menjamin masyarakat terbebas dari dampak psikologis akibat COVID-19. Masalah psikososial seperti kecemasan, depresi, dan posttraumatic stress disorder (PTSD) masih banyak dialami oleh masyarakat. Tujuan dari studi ini adalah untuk memperoleh gambaran penerapan adaptasi kebiasaan baru dan perubahan masalah psikososial akibat pandemi COVID-19. Studi ini menggunakan metode descriptive case study yang melibatkan enam responden yang diukur masalah psikososial, diberikan dukungan kesehatan jiwa psikososial terkait COVID-19, dan diukur penerapan adaptasi kebiasaan barunya. Pengukuran masalah psikososial menggunakan instrumen Self-Reporting Questionnaire dan penerapan adaptasi kebiasaan baru dihitung kenaikan rata-rata perilaku, dan keduanya diukur sebelum diberikan dukungan kesehatan jiwa psikososial COVID-19, hari ke-7, dan hari ke-14 setelah diberikan dukungan kesehasatan jiwa psikososial. Hasil diperoleh bahwa terjadi peningkatan rata-rata perilaku sehat adaptasi kebiasaan baru $(92,38 \%-97,02 \%)$ yang meliputi peningkatan imunitas fisik, peningkatan imunitas jiwa, pencegahan penularan COVID-19 secara fisik, pencegahan masalah kesehatan jiwa terkair COVID-19 pada individu, keluarga, dan masyarakat. Hasil juga diperoleh terjadi perubahan masalah psikososial pada tiga responden yang sebelumnya mengalami gangguan mental emosional $(50 \%)$ dan PTSD $(50 \%)$ menjadi sehat $(100 \%)$ baik secara fisik dan psikososial. Penerapan adaptasi kebiasaan baru yang terintegrasi dengan kegiatan sehari-hari sangat penting agar terhidar dari penularan COVID-19 dan masalah kesehatan jiwa psikososial akibat COVID-19. Perilaku baru tersebut diharapkan dapat menjadi budaya perilaku sehat dalam beradaptasi dengan perubahan-perubahan akibat COVID-19.
\end{abstract}

\section{Kata Kunci: Adaptasi Kebiasaan Baru, Masalah Psikososial, Pandemi COVID-19, Perilaku Sehat}

\section{ABSTRACT}

Coronavirus Diseases 2019 (COVID-19) not only affects a person's physical condition, but also has a psychological impact. The incidence of COVID-19 is still increasing and accompanied by an increasing cure rate, this condition does not guarantee that people are free from the psychological impact of COVID-19. Psychosocial problems such as anxiety, depression, and post-traumatic stress disorder (PTSD) are still experienced by many people. The aim of this study is to obtain an overview of the application of adaptation to new habits and changes in psychosocial problems due to the COVID-19 
pandemic. This study used a descriptive case study method involving six respondents who were measured for psychosocial problems, provided psychosocial mental health support related to COVID-19, and measured the application of their new habit adaptations. Measurement of psychosocial problems using the Self-Reporting Questionnaire instrument and the application of new habit adaptations calculated the average increase in behavior, and both were measured before being provided with COVID-19 psychosocial mental health support, day 7 and day 14 after being given psychosocial mental health support. The results showed that there was an increase in the average healthy behavior adaptation to new habits $(92.38 \%-97.02 \%)$ which includes increased physical immunity, increased mental immunity, prevention of physical transmission of COVID-19, prevention of mental health problems related to COVID-19. in individuals, families, and communities. The results also showed that there was a change in psychosocial problems in three respondents who previously experienced mental emotional disorders (50\%) and PTSD (50\%) to be healthy (100\%) both physically and psychosocial. The application of adaptation to new habits that are integrated with daily activities is very important to avoid transmission of COVID-19 and psychosocial mental health problems due to COVID-19. This new behavior is expected to become a culture of healthy behavior in adapting to changes caused by COVID-19.

\section{Keywords: Adaptation to New Habits,COVID-19 Pandemic, Healthy Behavior, Psychosocial Problems}

\section{PENDAHULUAN}

Coronavirus Diseases 2019 (COVID-19) telah ditetapkan sebagai pandemi oleh World Health Organization (WHO) pada tanggal 11 Maret 2020 dikarenakan COVID-19 telah menyebar ke berbagai negara di dunia (WHO, 2020). Kasus COVID-19 pertama di Indonesia, diumumkan oleh pemerintah pada 2 Maret 2020 (Dirjen Pencegahan dan pengendalian penyakit Kemenkes RI, 2021), sampai saat ini kasus COVID-19 di Indonesia terus bertambah. Selain itu angka kesembuhan juga menunjukkan semakin meningkat. Meskipun prevalensi dan angka kesembuhan COVID-19 yang meningkat, masyarakat saat ini masih merasakan berbagai dampak dari COVID-19.

Dampak dari COVID-19 yang dirasakan salah satunya adalah dampak psikologis, masalah psikososial, ansietas merupakan dampak psikologis yang sering muncul (Bao, 2020; Xiong et al., 2020). Kondisi ansietas yang memanjang dapat mengakibatkan berbagai masalah kesehatan jiwa misalnya gangguan tidur dan dapat mengakibatkan depresi (Baka, 2021; Setyaningrum \& Yanuarita, 2020; Zhou et al., 2021). Penelitian sebelumnya juga menjelaskan bahwa pandemic COVID-19 dapat menyebabkan terjadinya gejala psikotik dan posttraumatic stress disorder (PTSD) (Keliat et al., 2020). Berbagai macam situasi terkait kondisi pandemi COVID-19 dapat mengakibatkan berbagai masalah psikologis.

Situasi terkait kondisi pandemi COVID-19 yang tidak menentu, kondisi terkonfirmasi positif COVID-19, aturan aturan terkait protokol kesehatan seperti pembatasan sosial dan karantina dapat mengakubatkan masalah psikologis terutama kecemasan (Giusti et al., 2020; Moghanibashi-Mansourieh, 2020). Ketakutan akan tertular, kondisi ekonomi yang tidak stabil, kehilangan pekerjaan, dan kekhawatiran terhadap kondisi kesehatan diri sendiri dan keluarga juga mengakibatkan individu mengalami kecemasan (Baka, 2021; Brooks et al., 
2020; Holmes et al., 2020). Perubahan kebiasaan seperti sekolah daring, bekerja dari rumah, dan pembatasan pertemuan secara fisik juga merupakan situasi yang dapat meningkatkan masalah psikososial (The Canadian Mental Health Association (CMHA), 2020). Masyarakat harus dapat beradaptasi terhadap perubahan atau situasi-situasi terkait pandemi COVID-19.

Dukungan kesehatan jiwa dan psikososial merupakan kegiatan untuk membantu proses adaptasi pada masyarakat. Pemberian edukasi tentang perilaku atau kebiasaan baru merupakan salah satu upaya mencegah, menangani, dan mengelola masalah kesehatan jiwa psikososial yang muncul akibat pandemi COVID-19. (Keliat et al., 2020). Dukungan sosial berupa perhatian dan bantuan dapat memberikan dampak perlindungan bagi individu dalam menghadapi permasalahan terkait kondisi pandemi COVID-19 (Psychosocial Centre, 2020). Dukungan sosial yang tepat dapat memberikan manfaat bagi individu dalam mengelola stress, mengatur respons terhadap stressor, dan mencegah timbulnya masalah kesehata jiwa psikososial (Keliat et al., 2020). Pemberian edukasi tentang dukungan kesehatan jiwa psikososial COVID-19 merupakan tahapan pertama yang diberikan diikuti dengan pelaksanaan adaptasi kebiasaan baru agar masyarakat dapat mencegah dan mengelola masalah kesehatan jiwa psikososial.

Keenam responden (An. K, An. R, An. A, An. N, An. F dan An. E) merupakan siswi anggota PMR di SMA Negeri 1 Sumberpucung Malang. Usia dari responden 16 tahun, kecuali An. F yang berusia 15 tahun. Tiga orang responden memiliki jarak rumah ke sekolah $<2 \mathrm{~km}$ (An. K, R dan A), dua orang menempuhnya dengan jalan kaki dan satu orang menggunakan kendaraan pribadi, tidak sering kontak dengan banyak orang namun hasil assesment dengan Self-Reporting Questionnaire (SRQ) pada An. K menunjukkan dirinya mengalami gejala gangguan mental emosional (GME) dan PTSD. Tiga orang responden memiliki jarak rumah ke sekolah $>2 \mathrm{~km}$ (An. N, F dan E), dua orang menempuhnya dengan Kendaraan pribadi(An. N dan E), tidak sering kontak dengan banyak orang namun hasil assesment dengan Self-Reporting Questionnaire (SRQ) pada An. N menunjukkan dirinya mengalami gejala gangguan mental emosional (GME) dan PTSD. An. F menggunakan kendaraan umum yang berpotensi sering kontak dengan banyak orang orang, hasil assesment dengan Self-Reporting Questionnaire (SRQ) pada An. F menunjukkan dirinya mengalami gejala gangguan mental emosional (GME) dan PTSD.

Berdasarkan uraian latar belakang dan perbedaan kondisi kesehatan jiwa psikososial pada enam responden tersebut membuat penulis tertarik untuk menulis studi kasus tentang penerapan adaptasi kebiasaan baru dan masalah psikososial akibat pandemi COVID-19 pada siswi anggota PMR SMAN 1 Sumberpucung Malang. Tujuan dari studi ini adalah untuk mendapatkan gambaran penerapan adaptasi kebiasaan baru dan perubahan masalah psikososial akibat pandemi COVID-19.

\section{METODE}

Artikel ini ditulis menggunakan studi kasus dengan metode deskriptif. Penulis menggambarkan kasus yang diperoleh dan menjelaskan isi dari kasus tersebut. Fenomena-fenomena dalam kasus tersebut kemudian penulis telaah dengan menggunakan literatur dan artikel-artikel di jurnal hasil penelitian yang sudah ada.

\section{HASIL dan PEMBAHASAN}

Tabel 1. Karakteristik Responden ( $\mathrm{n}=6$ ) 


\begin{tabular}{|c|c|c|c|c|}
\hline Resp & Usia & $\begin{array}{c}\text { Jarak } \\
\text { rumah } \\
\text { ke } \\
\text { sekolah }\end{array}$ & $\begin{array}{l}\text { Cara ke } \\
\text { sekolah }\end{array}$ & $\begin{array}{c}\text { Potensi } \\
\text { kontak } \\
\text { dengan } \\
\text { banyak } \\
\text { orang }\end{array}$ \\
\hline
\end{tabular}

\begin{tabular}{|c|c|c|c|c|c|}
\hline \multirow[t]{3}{*}{ Resp } & \multirow{2}{*}{\multicolumn{2}{|c|}{$\begin{array}{c}\text { Pre } \\
\text { Hari 1 } \\
\end{array}$}} & \multirow{2}{*}{\multicolumn{3}{|c|}{$\begin{array}{c}\text { Post } \\
\text { Hari 14 }\end{array}$}} \\
\hline & & & & & \\
\hline & Fisik & Psiko & Fisik & \multicolumn{2}{|c|}{ Psiko } \\
\hline An.K & Sehat & $\begin{array}{l}\text { GME } \\
\text { PTSD }\end{array}$ & Sehat & \multicolumn{2}{|c|}{ Sehat } \\
\hline An.R & Sehat & Sehat & Sehat & \multicolumn{2}{|c|}{ Sehat } \\
\hline An.A & Sehat & Sehat & Sehat & \multicolumn{2}{|c|}{ Sehat } \\
\hline An.E & Sehat & Sehat & Sehat & \multicolumn{2}{|c|}{ Sehat } \\
\hline An.N & Sehat & $\begin{array}{l}\text { GME } \\
\text { PTSD }\end{array}$ & Sehat & \multicolumn{2}{|c|}{ Sehat } \\
\hline An.F & Sehat & $\begin{array}{l}\text { GME } \\
\text { PTSD } \\
\end{array}$ & Sehat & \multicolumn{2}{|c|}{ Sehat } \\
\hline An.K & 16 & $<2 \mathrm{~km}$ & \multicolumn{2}{|c|}{ Jalan kaki } & $\begin{array}{r}\text { Tidak } \\
\text { sering } \\
\text { kontak } \\
\end{array}$ \\
\hline An.R & 16 & $<2 \mathrm{~km}$ & \multicolumn{2}{|c|}{ Jalan kaki } & $\begin{array}{r}\text { Tidak } \\
\text { sering } \\
\text { kontak } \\
\end{array}$ \\
\hline An.A & 16 & $<2 \mathrm{~km}$ & \multicolumn{2}{|c|}{$\begin{array}{c}\text { Kendaraan } \\
\text { Pribadi }\end{array}$} & $\begin{array}{r}\text { Tidak } \\
\text { sering } \\
\text { kontak } \\
\end{array}$ \\
\hline An.E & 16 & $>2 \mathrm{~km}$ & \multicolumn{2}{|c|}{$\begin{array}{c}\text { Kendaraan } \\
\text { Pribadi }\end{array}$} & $\begin{array}{r}\text { Tidak } \\
\text { sering } \\
\text { kontak } \\
\end{array}$ \\
\hline An.N & 16 & $>2 \mathrm{~km}$ & \multicolumn{2}{|c|}{$\begin{array}{c}\text { Kendaraan } \\
\text { Pribadi }\end{array}$} & $\begin{array}{l}\text { Tidak } \\
\text { sering } \\
\text { kontak }\end{array}$ \\
\hline An.F & 15 & $>2 \mathrm{~km}$ & \multicolumn{2}{|c|}{$\begin{array}{c}\text { Kendaraan } \\
\text { Umum }\end{array}$} & $\begin{array}{r}\text { Sering } \\
\text { kontak } \\
\end{array}$ \\
\hline
\end{tabular}

Berdasarkan tabel 1 diperoleh tiga responden yang mempunyai jarak rumah ke sekolah $<2 \mathrm{~km}$, tidak sering kontak dengan banyak orang, dua responden mencapainya dengan jalan kaki dan satu responden menggunakan kendaraan pribadi. Tiga responden mempunyai jarak rumah ke sekolah $>2 \mathrm{~km}$, dua responden menggunakan kendaraan pribadi, tidak sering kontak dengan banyak orang, satu responden mencapainya dengan kendaraan umum dan sering kontak dengan banyak orang.

Keenam responden diberikan edukasi tentang dukungan kesehatan jiwa psikososial melalui pelatihan 1 hari.
Materi edukasi terkait adaptasi kebiasaan baru atau perilaku sehat. Edukasi dilaksanakan secara daring dengan menekankan peningkatan pengetahuan dan ketrampilan dalam melaksanakan adaptasi kebiasaan baru secara mandiri. Pelaksanaan atau penerapan adaptasi kebiasaan baru yang telah diajarkan keenam responden dipantau dan didampingi oleh fasilitator selama 2 minggu. Pengukuran kondisi kesehatan fisik, psikososial, serta rata-rata penerapan adaptasi kebiasaan baru dilakukan setiap minggu.

Tabel 2. Perubahan Masalah Fisik dan Psikososial pada Responden dengan SRQ( $n=6)$

Hasil akhir diperoleh bahwa keenam responden dalam keadaan sehat secara fisik. Tiga dari enam responden yang pada pengukuran kesehatan psikososial pada hari pertama mengalami GME dan PTSD menjadi seluruhnya sehat atau tidak mengalami masalah psikososial.

Pelaksanaan adaptasi kebiasaan baru atau penerapan perlaku sehat juga terjadi peningkatan rata-rata dua mingguan pada keenam responden. Berikut tabel perubahan penerapan perilaku sehat pada responden.

Peningkatan adaptasi kebiasaan baru untuk peningkatan imunitas fisik selama dua minggu diperoleh 92,38\%. Rerata peningkatan sebesar $16,19 \%$ (Tabel 3)

Tabel 3. Perubahan Adaptasi Kebiasaan Baru: Peningkatan Imunitas Fisik $(n=6)$

\begin{tabular}{cccccc}
\hline & & \multicolumn{2}{l}{ Rerata Per minggu } & \\
& Adaptasi & & & & \\
& Kebiasaan & & & & \\
N & Baru : & & & & \\
\cline { 3 - 5 } o & Peningkata & Pre & Post & Post & \\
& n Imunitas & & 1 & 2 & \\
& Fisik & & H7 & H14
\end{tabular}




\begin{tabular}{|c|c|c|c|c|c|}
\hline 1 & $\begin{array}{l}\text { Makan } \\
\text { Bergizi }\end{array}$ & 0 & $\begin{array}{l}92,8 \\
6\end{array}$ & $\begin{array}{l}100,0 \\
0\end{array}$ & $\begin{array}{l}\text { PO 1- P } \\
\text { Meningk } \\
7,14 \%\end{array}$ \\
\hline 2 & $\begin{array}{l}\text { Minum } \\
\text { liter/hari }\end{array}$ & 0 & $\begin{array}{l}69,0 \\
5\end{array}$ & 83,33 & $\begin{array}{l}\text { PO 1- P } \\
\text { Meningk } \\
14,29 \%\end{array}$ \\
\hline 3 & $\begin{array}{l}\text { Olahraga } 15 \\
\text { menit }\end{array}$ & 0 & $\begin{array}{l}59,5 \\
2\end{array}$ & 95,24 & $\begin{array}{l}\text { PO 1- P } \\
\text { Meningk } \\
35,71 \%\end{array}$ \\
\hline 4 & Berjemur & 0 & $\begin{array}{l}69,0 \\
5\end{array}$ & 88,10 & $\begin{array}{l}\text { PO 1- P } \\
\text { Meningk } \\
19,05 \% \\
\end{array}$ \\
\hline 5 & $\begin{array}{l}\text { Istirahat } 6- \\
7 \text { jam }\end{array}$ & 0 & $\begin{array}{l}90,4 \\
8\end{array}$ & 95,24 & $\begin{array}{l}\text { PO 1- P } \\
\text { Meningk } \\
4,76 \% \\
\end{array}$ \\
\hline & Rata-rata & 0 & $\begin{array}{l}76,1 \\
9\end{array}$ & 92,38 & $\begin{array}{l}\text { PO 1- P } \\
\text { Meningk } \\
16,19 \%\end{array}$ \\
\hline
\end{tabular}

\begin{tabular}{cccll}
\hline & 0 & 90,0 & 94,4 & PO 1- PO 2 \\
& & 8 & 4 & $\begin{array}{l}\text { Meningkat } \\
4,37 \%\end{array}$ \\
Rata rata & & & & $4,37 \%$ \\
\hline
\end{tabular}

Tabel 5. Perubahan Adaptasi Kebiasaan

Baru: Pencegahan Penularan COVID-19

Secara Fisik $(n=6)$

\begin{tabular}{|c|c|c|c|c|c|}
\hline \multirow[b]{2}{*}{$\begin{array}{l}\mathbf{N} \\
\mathbf{0}\end{array}$} & \multirow{2}{*}{$\begin{array}{c}\text { Adaptasi } \\
\text { Kebiasaan } \\
\text { Baru : } \\
\text { Pencegaha } \\
\text { n } \\
\text { Penularan } \\
\text { COVID-19 } \\
\text { Secara } \\
\text { Fisik }\end{array}$} & \multicolumn{3}{|c|}{ Rerata Per minggu } & \multirow[b]{2}{*}{$\begin{array}{c}\text { Keteranga } \\
\mathbf{n}\end{array}$} \\
\hline & & Pre & $\begin{array}{l}\text { Post } \\
1\end{array}$ & $\begin{array}{l}\text { Post } \\
2\end{array}$ & \\
\hline 1 & $\begin{array}{l}\text { Jarak Sosial } \\
2 \text { meter }\end{array}$ & 0 & 95,24 & $\begin{array}{l}100 \\
00\end{array}$ & $\begin{array}{c}\text { PO } 1-\text { PO } \\
2 \\
\text { Meningkat } \\
4,76 \% \\
\end{array}$ \\
\hline 2 & $\begin{array}{l}\text { Jarak Fisik } \\
2 \text { meter }\end{array}$ & 0 & 88,10 & $\begin{array}{l}95,2 \\
4\end{array}$ & $\begin{array}{c}\text { PO } 1-\text { PO } \\
2 \\
\text { Meningkat } \\
7,14 \%\end{array}$ \\
\hline 3 & $\begin{array}{l}\text { Pakai } \\
\text { Masker }\end{array}$ & 0 & $\begin{array}{l}100,0 \\
0\end{array}$ & $\begin{array}{l}100 \\
00\end{array}$ & $\begin{array}{c}\text { PO } 1-\mathrm{PO} \\
2 \\
\text { Meningkat } \\
0 \%\end{array}$ \\
\hline 4 & Cuci tangan & 0 & 97,62 & $\begin{array}{l}100 \\
00\end{array}$ & $\begin{array}{c}\text { PO } 1-\text { PO } \\
2 \\
\text { Meningkat } \\
2,38 \%\end{array}$ \\
\hline 5 & $\begin{array}{l}\text { Tinggal di } \\
\text { rumah/ } \\
\text { tidak } \\
\text { berkerumun }\end{array}$ & 0 & 97,62 & $\begin{array}{l}100 \\
00\end{array}$ & $\begin{array}{c}\text { PO 1- PO } \\
2 \\
\text { Meningkat } \\
2,38 \% \\
\end{array}$ \\
\hline 6 & $\begin{array}{l}\text { Etika Batuk } \\
\text { dan Bersin }\end{array}$ & 0 & 95,24 & $\begin{array}{l}95,2 \\
4\end{array}$ & $\begin{array}{c}\text { PO } 1-\text { PO } \\
2 \\
\text { Meningkat } \\
0 \%\end{array}$ \\
\hline 7 & $\begin{array}{l}\text { Membersih } \\
\text { kan } \\
\text { Handphone }\end{array}$ & 0 & 59,52 & $\begin{array}{l}61,9 \\
0\end{array}$ & $\begin{array}{c}\text { PO 1- PO } \\
2 \\
\text { Meningkat } \\
2,38 \%\end{array}$ \\
\hline & Rata rata & 0 & 90,48 & $\begin{array}{l}93,2 \\
0\end{array}$ & $\begin{array}{c}\text { PO } 1-\mathrm{PO} \\
2 \\
\text { Meningkat } \\
2,72 \%\end{array}$ \\
\hline
\end{tabular}

Tabel 4. Perubahan Adaptasi Kebiasaan Baru: Peningkatan Imunitas Jiwa $(n=6)$

\begin{tabular}{|c|c|c|c|c|c|}
\hline \multirow[b]{2}{*}{$\begin{array}{l}\mathbf{N} \\
\mathbf{0}\end{array}$} & \multirow{2}{*}{$\begin{array}{c}\text { Adaptasi } \\
\text { Kebiasaan } \\
\text { Baru : } \\
\text { Peningkata } \\
\text { n Imunitas } \\
\text { Jiwa }\end{array}$} & \multicolumn{2}{|c|}{$\begin{array}{l}\text { Rerata } \\
\text { minggu }\end{array}$} & Per & \multirow[b]{2}{*}{ Keterang } \\
\hline & & Pre & $\begin{array}{l}\text { Post } \\
1\end{array}$ & $\begin{array}{l}\text { Post } \\
2\end{array}$ & \\
\hline 1 & Fisik Rilek & 0 & $\begin{array}{l}90,4 \\
8\end{array}$ & $\begin{array}{l}92,8 \\
6\end{array}$ & $\begin{array}{l}\text { PO 1- PO } \\
\text { Meningkat } \\
2,38 \%\end{array}$ \\
\hline 2 & $\begin{array}{l}\text { Emosi } \\
\text { Positif }\end{array}$ & 0 & $\begin{array}{l}95,2 \\
4\end{array}$ & $\begin{array}{l}97,6 \\
2\end{array}$ & $\begin{array}{l}\text { PO 1- PO } \\
\text { Meningkat } \\
2,38 \%\end{array}$ \\
\hline 3 & $\begin{array}{l}\text { Pikiran } \\
\text { Positif }\end{array}$ & 0 & $\begin{array}{l}95,2 \\
4\end{array}$ & $\begin{array}{l}100, \\
00\end{array}$ & $\begin{array}{l}\text { PO 1- PO } \\
\text { Meningkat } \\
4,76 \%\end{array}$ \\
\hline 4 & $\begin{array}{l}\text { Perilaku } \\
\text { Positif }\end{array}$ & 0 & $\begin{array}{l}97,6 \\
2\end{array}$ & $\begin{array}{l}100 \\
00\end{array}$ & $\begin{array}{l}\text { PO 1- PO } \\
\text { Meningkat } \\
2,38 \% \\
\end{array}$ \\
\hline 5 & $\begin{array}{l}\text { Relasi } \\
\text { Positif }\end{array}$ & 0 & $\begin{array}{l}78,5 \\
7\end{array}$ & $\begin{array}{l}92,8 \\
6\end{array}$ & $\begin{array}{l}\text { PO 1- PO } \\
\text { Meningkat } \\
14,29 \%\end{array}$ \\
\hline 6 & $\begin{array}{l}\text { Spiritual } \\
\text { Positif }\end{array}$ & 0 & $\begin{array}{l}83,3 \\
3\end{array}$ & $\begin{array}{l}83,3 \\
3\end{array}$ & $\begin{array}{l}\text { PO 1- PO } \\
\text { Meningkat } \\
0 \%\end{array}$ \\
\hline
\end{tabular}

Peningkatan adaptasi kebiasaan baru untuk peningkatan imunitas jiwa selama dua minggu diperoleh 94,44\%. Rerata peningkatan sebesar $16,19 \%$ (Tabel 4). Peningkatan adaptasi kebiasaan baru untuk Pencegahan penularan selama dua minggu diperoleh 
93,20\%. Rerata peningkatan sebesar $2,72 \%$ (Tabel 5)

Tabel 6. Perubahan Adaptasi Kebiasaan Baru: Pencegahan Masalah Kesehatan Jiwa Terkait COVID-19 pada Individu

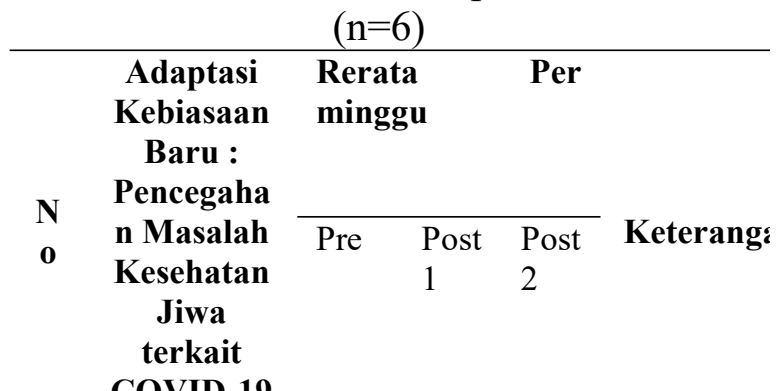

\begin{tabular}{llllll}
\multicolumn{1}{c}{ COVID-19 } & & & & \\
\hline 1 & Tarik Nafas & 0 & 78,5 & 90,4 & PO 1- PO
\end{tabular}

$\begin{array}{llll}\text { dalam } & 7 & 8 & \text { Meningk } \varepsilon\end{array}$

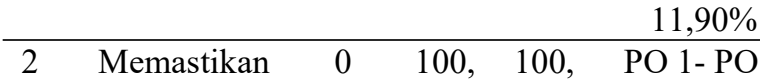
Informasi $\quad 00 \quad 00 \quad$ Meningke valid $0 \%$

3 Melakukan $0 \quad 100, \quad 100, \quad$ PO 1- PO tindakan sesuai anjuran pemerintah

\begin{tabular}{llllll}
\hline 4 & Evaluasi & 0 & 92,8 & 97,6 & PO 1- PO \\
& Tindakan & & 6 & 2 & Meningk $\varepsilon$
\end{tabular} yang dilakukan Rata Rata 0

\begin{tabular}{|c|c|c|c|c|c|}
\hline 1 & $\begin{array}{l}\text { Pertemuan } \\
\text { keluarga }\end{array}$ & 0 & $\begin{array}{l}47,6 \\
2\end{array}$ & $\begin{array}{l}66,6 \\
7\end{array}$ & $\begin{array}{c}\text { PO 1- PO } 2 \\
\text { Meningkat } \\
19,05 \%\end{array}$ \\
\hline 2 & $\begin{array}{l}\text { Klg } \\
\text { mengetahui } \\
\text { masalah } \\
\text { kes. } \\
\text { Covid19 }\end{array}$ & 0 & $\begin{array}{l}100, \\
00\end{array}$ & $\begin{array}{l}100, \\
00\end{array}$ & $\begin{array}{c}\text { PO 1- PO } 2 \\
\text { Meningkat } \\
0 \%\end{array}$ \\
\hline 3 & $\begin{array}{l}\text { Klg mampu } \\
\text { mengambil } \\
\text { keputusan } \\
\text { kesehatan }\end{array}$ & 0 & $\begin{array}{l}100, \\
00\end{array}$ & $\begin{array}{l}100, \\
00\end{array}$ & $\begin{array}{c}\text { PO 1- PO } 2 \\
\text { Meningkat } \\
0 \%\end{array}$ \\
\hline 4 & $\begin{array}{l}\text { Klg mampu } \\
\text { merawat }\end{array}$ & 0 & $\begin{array}{l}100, \\
00\end{array}$ & $\begin{array}{l}100, \\
00\end{array}$ & $\begin{array}{c}\text { PO 1- PO } 2 \\
\text { Meningkat } \\
0 \%\end{array}$ \\
\hline 5 & $\begin{array}{l}\text { Klg mampu } \\
\text { menciptaka } \\
\text { n suasanan } \\
\text { yang } \\
\text { kondusif }\end{array}$ & 0 & $\begin{array}{l}100, \\
00\end{array}$ & $\begin{array}{l}100, \\
00\end{array}$ & $\begin{array}{c}\text { PO 1- PO } 2 \\
\text { Meningkat } \\
0 \%\end{array}$ \\
\hline 6 & $\begin{array}{l}\text { Klg mampu } \\
\text { menggunak } \\
\text { an fasilitas } \\
\text { kes } \\
\text { Masyarakat }\end{array}$ & 0 & $\begin{array}{l}100, \\
00\end{array}$ & $\begin{array}{l}100, \\
00\end{array}$ & $\begin{array}{c}\text { PO 1- PO } 2 \\
\text { Meningkat } \\
0 \%\end{array}$ \\
\hline & Rata rata & 0 & $\begin{array}{l}91,2 \\
7\end{array}$ & $\begin{array}{l}94,4 \\
4\end{array}$ & $\begin{array}{c}\text { PO 1- PO } 2 \\
\text { Meningkat } \\
3,17 \%\end{array}$ \\
\hline \multicolumn{6}{|c|}{ Masyarakat } \\
\hline & $\begin{array}{l}\text { Masyarakat } \\
\text { Gotong } \\
\text { Royong }\end{array}$ & 0 & $\begin{array}{l}100, \\
00\end{array}$ & $\begin{array}{l}100, \\
00\end{array}$ & $\begin{array}{c}\text { PO 1- PO } 2 \\
\text { Meningkat } \\
0 \%\end{array}$ \\
\hline
\end{tabular}

Peningkatan adaptasi kebiasaan baru untuk peningkatan imunitas jiwa pada keluarga selama dua minggu diperoleh

Peningkatan adaptasi kebiasaan baru untuk peningkatan imunitas jiwa pada individu selama dua minggu diperoleh $97,02 \%$. Rerata peningkatan sebesar $4,17 \%$

Tabel 7. Perubahan Adaptasi Kebiasaan

Baru: Pencegahan Masalah Kesehatan

Jiwa Terkait COVID-19 pada Keluarga dan Masyarakat $(n=6)$

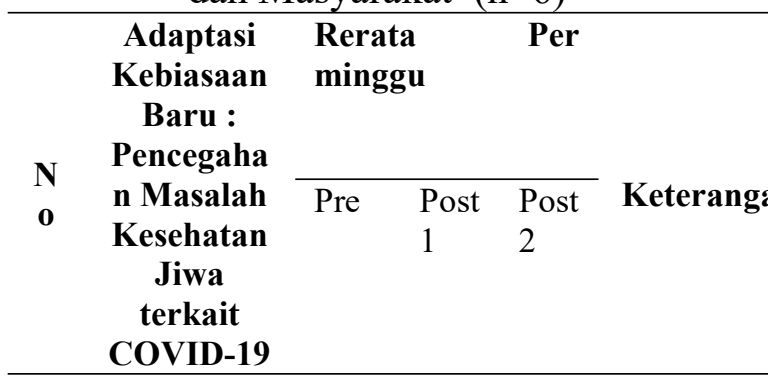

Keluarga

$94,44 \%$. Rerata peningkatan sebesar $3,17 \%$ dan pada masyarakat mencapai $100 \%$.

Peningkatan kesehatan jiwa merupakan aspek penting dalam kehidupan. Masyarakat lebih rentan terhadap masalah kesehatan jiwa psikososial pada situasi pandemi COVID19. Gangguan kesehatan jiwa psikososial pada masyarakat dapat disebabkan oleh kondisi pandemi COVID-19. Hal tersebut dibuktikan pada hasil studi ini yang menyatakan bahwa $50 \%$ responden mengalami masalah kesehatan jiwa psikososial berupa GME dan PTSD. Hal tersebut sesuai dengan studi sebelumnya yang menyebutkan bahwa adanya wabah penyakit fisik yang mudah menular, menyebar luas dan cepat, serta adanya 
tekanan dan kesulitan pada masyarakat menimbulkan kecemasan dan depresi (Gao et al., 2020; Van Bortel et al., 2016). Masyarakat lebih rentan terhadap depresi dikarenakan paparan stressor yang terjadi secara terus menerus selama kondisi pandemi COVID-19 (Bao, 2020). Pandemi COVID-19 juga dapat menyebabkan reaksi stres akut, serangan panik, PTSD, kecemasan, depresi, dan bahkan kecenderungan bunuh diri (Yadav, 2021; Zhang et al., 2021). Kondisi pandemi COVID-19 memunculkan respon yang beragam yang mengindikasikan suatu masalah kesehatan jiwa dan psikososial.

Karakteristik yang sama tetapi kondisi kesehatan yang berbeda didapatkan pada studi ini, $50 \%$ responden dinyatakan sehat dan tidak mengalami masalah kesehatan jiwa psikososial dan $50 \%$ responden mengalami GME dan PTSD. Kondisi kesehatan yang berbeda dapat disebabkan oleh pengelolaan stressor yang terjadi selama kondisi pandemi.Peningkatan risiko munculnya masalah kesehatan jiwa dan masalah psikososial dapat disebabkan karena respon kognitif yang maladaptif, emosi negatif, dan rendahnya sikap optimis pada perubahan dari situasi pandemi COVID-19 (Taylor et al., 2018). Kondisi kesehatan jiwa psikososial dapat mempengaruhi imunitas seseorang, kondisi stres, cemas serta masalah kesehatan jiwa yang terjadi dapat menurunkan imunitas seseorang.

Turunnya respon imun akibat adanya masalah kesehatan jiwa psikososial dapat menyebabkan individu lebih rentan tertular COVID-19. Dukungan kesehatan jiwa psikososial merupakan bentuk dukungan sosial yang dapat diberikan kepada masyarakat pada pandemi COVID-19 ini. Dukungan sosial berupa perhatian dan bantuan dapat memberikan dampak perlindungan bagi individu dalam menghadapi permasalahannya (Keliat et al., 2020; Psychosocial Centre, 2020). Masalah kesehatan jiwa psikososial dapat dicegah melalui pemberian dukungan sosial yang tepat. Pengelolaan stress, dan pengaturan respon terhadap stress merupakan salah satu manfaat dari pemberian dukungan sosial (Brooks et al., 2020; Kunzler et al., 2021). Dukungan kesehatan jiwa psikososial COVID-19 diberikan melalui tahapan edukasi dan pendampingan implementasi dari adaptasi kebiasaan baru.

Studi ini menunjukkan bahwa terjadi peningkatan adaptasi kebiasaan baru peningkatan imunitas fisik 92,38\%, dengan rata rata peningkatan $16,19 \%$. Hasil tersebut menunjukkan bahwa keenam responden telah melaksanakan hampir seluruh aktifitas untuk adaptasi kebiasaan baru peningakatan imunitas fisik.

Studi ini menunjukkan bahwa tiga responden mengalami masalah psikososial yaitu GME dan PTSD, kondisi tersebut dapat yang dapat memicu diproduksinya hormon stres kortisol yang berakibat penurunan imunitas (Keliat et al., 2020). Studi ini menunjukkan selama dua minggu penerapan adaptasi kebiasaan baru peningkatan ketahanan/imunitas jiwa diperoleh hasil 94,44\%, dengan rata-rata peningkatan sebesar $16,19 \%$ Hal tersebut memberikan dampak terjadinya perubahan masalah psikososial yang dialami oleh tiga responden dalam studi ini.

Tingkat kecemasan dan stress dapat diurunkan dengan pemberian tindakan kombinasi relaksasi otot progresif dan relaksasi napas dalam (Hidayati et al., 2019; Pramono, 2019). Latihan nafas dalam dan relaksasi otot progresif yang teratur menurunkan GME dan PTSD responden dalam studi ini. Emosi yang positif dapat meningkatkan kualitas kesehatan jiwa psikososial karena emosi positif dapat menurunkan respon sres, meningkatkan daya tahan tubuh, dan membuat suasana hati yang lebih baik. Pikiran positif dapat dilakukan 
dengan hipnotis lima jari, berfikir/afirmasi positif, dan latihan menghentikan pikiran yang mengganggu (Keliat et al., 2020).

Studi yang sudah dilakukan sebelumnya menyebutkan bahwa setiap individu berpotensi tertular COVID-19 meskipun dengan tingkat risiko terlular yang berbeda - beda (Siagian, 2020). Penerapan adaptasi kebiasaan baru pencegahan penularan COVID-19 secara fisik diperoleh rata-rata 93,20\%. Meskipun belum mancapai 100\%, namun keenam responden tetap dalam kondisi sehat dan tidak tertular COVID-19 pada dua minggu penerapan adaptasi kebiasaan baru yang telah diajarkan. Studi ini menunjukkan hasil penerapan adaptasi kebiasan baru pencegahan masalah kesehatan jiwa psikososial pada individu $97,02 \%$, pada keluarga $94,44 \%$, dan pada masyarakat $100 \%$.

\section{KESIMPULAN DAN SARAN}

Adaptasi kebiasaan baru melalui dukungan kesehatan jiwa psikososial COVID-19 dapat diberikan pada siswa dan masyarakat. Penerapan adaptasi kebiasaan baru melalui program dukungan kesehatan jiwa psikososial COVID-19 selama dua minggu mengalami peningkatan rata-rata antara $92,38 \%$ - $100 \%$ pada setiap aspek komponen adaptasi kebiasaan barunya. Selain itu, masalah kesehatan jiwa psikososial yang dialami oleh tiga responden dalam penelitian ini juga mengalami perubahan, setelah dua minggu penerapan adaptasi kebisaan baru menjadi sehat dan tidak mengalami masalah psikososial seluruhnya. Oleh karena itu, penerapan adaptasi kebiasaan baru pada siswa dan masyarakat sangat penting mencegah penularan COVID-19 dan pencegan serta pengelolaan masalah kesehatan jiwa psikososial. Penerapan adaptasi kebiasaan baru terintegrasi dengan kegiatan sehari-hari diharapkan dapat menjadi budaya perilaku sehat dalam beradaptasi dengan perubahan- perubahan yang terjadi akibat pandemi COVID-19.

\section{DAFTAR PUSTAKA}

Baka, Ł. (2021). Coronavirus anxiety and exhaustion among Polish frontline healthcare workers - the mediation effect of insomnia. International Journal of Occupational Medicine and Environmental Health. https://doi.org/10.13075/ijomeh.1 896.01745

Bao, W. (2020). COVID -19 and online teaching in higher education: A case study of Peking University. Human Behavior and Emerging Technologies, 2(2), 113-115. https://doi.org/10.1002/hbe2.191

Brooks, S., Amlôt, R., Rubin, G. J., \& Greenberg, N. (2020).

Psychological resilience and posttraumatic growth in disasterexposed organisations: Overview of the literature. BMJ Military Health, 166(1), 52-56. https://doi.org/10.1136/jramc2017-000876

Dirjen Pencegahan dan pengendalian penyakit Kemenkes RI. (2021).

Petunjuk Teknis Pelaksanaan Vaksinasi dalam Rangka Penanggulangan Pandemi Corona Virus Disease 2019 (COVID-19). Kementerian Kesehatan Republik Indonesia. Gao, Y., Yan, L., Huang, Y., Liu, F., Zhao, Y., Cao, L., Wang, T., Sun, Q., Ming, Z., Zhang, L., Ge, J., Zheng, L., Zhang, Y., Wang, H., Zhu, Y., Zhu, C., Hu, T., Hua, T., Zhang, B., ... Rao, Z. (2020). Structure of the RNA-dependent RNA polymerase from COVID19 virus. Science, 368(6492), 779-782.

https://doi.org/10.1126/science.ab b7498

Giusti, E. M., Pedroli, E., D’Aniello, G. E., Stramba Badiale, C., 
Pietrabissa, G., Manna, C., Stramba Badiale, M., Riva, G., Castelnuovo, G., \& Molinari, E. (2020). The Psychological Impact of the COVID-19 Outbreak on Health Professionals: A CrossSectional Study. Frontiers in Psychology, 11, 1684. https://doi.org/10.3389/fpsyg.202 0.01684

Hidayati, L., Keliat, B., \& Wardani, I. (2019). Combination of Thought Stopping Therapy and Progressive Muscle Relaxation to Reduce Anxiety. Proceedings of the Third International Conference on Sustainable Innovation 2019 Health Science and Nursing (IcoSIHSN 2019). Proceedings of the Third International Conference on Sustainable Innovation 2019 - Health Science and Nursing (IcoSIHSN 2019), Yogyakarta, Indonesia. https://doi.org/10.2991/icosihsn19.2019.45

Holmes, E. A., O'Connor, R. C., Perry, V. H., Tracey, I., Wessely, S., Arseneault, L., Ballard, C., Christensen, H., Cohen Silver, R., Everall, I., Ford, T., John, A., Kabir, T., King, K., Madan, I., Michie, S., Przybylski, A. K., Shafran, R., Sweeney, A., ... Bullmore, E. (2020). Multidisciplinary research priorities for the COVID-19 pandemic: A call for action for mental health science. The Lancet Psychiatry, 7(6), 547-560. https://doi.org/10.1016/S22150366(20)30168-1

Keliat, B. A., Marliana, T., Windarwati, H. D., Mubin, M. F., Sodikin, M. A., Kristaningsih, T., Prawiro, A., Trihadi, D., \& Lahargo, K. (2020). Mental Health And Psychosocial Support Covid-19: Keperawatan Jiwa (2nd ed.). Universitas Indonesia.
Kunzler, A. M., Röthke, N., Günthner, L., Stoffers-Winterling, J., Tüscher, O., Coenen, M., Rehfuess, E., Schwarzer, G., Binder, H., Schmucker, C., Meerpohl, J. J., \& Lieb, K. (2021). Mental burden and its risk and protective factors during the early phase of the SARS-CoV-2 pandemic: Systematic review and metaanalyses. Globalization and Health, 17(1), 34. https://doi.org/10.1186/s12992021-00670-y

Moghanibashi-Mansourieh, A. (2020). Assessing the anxiety level of Iranian general population during COVID-19 outbreak. Asian Journal of Psychiatry, 51, 102076. https://doi.org/10.1016/j.ajp.2020. 102076

Pramono, C. (2019). Pengaruh Teknik Relaksasi Otot Progresif Terhadap Tingkat Kecemasan Pasien Hemodialisis di RSUD Wonosari. 11.

Psychosocial Centre. (2020). Mental Health and Psychosocial Support for Staff, Volunteers and Communities in an Outbreak of Novel Coronavirus. http://www.pscentre.org/

Saswati, N. (2021). Demonstrasi Terapi Hipnotis Lima Jari pada Klien Diabetes Melitus. 4, 7.

Setyaningrum, W., \& Yanuarita, H. A. (2020). Pengaruh Covid-19 Terhadap Kesehatan Mental Masyarakat Di Kota Malang. Jurnal Ilmu Sosial Dan Pendidikan, 4(4), 7.

Siagian, T. H. (2020). Mencari Kelompok erisiko Tinggi Terinfeksi Virus Corona dengan Discourse Network Analysis. 9.

Taylor, S. E., Peplau, L. A., \& Sears, .. (2018). Psikologi Sosial Edisi Kedua Belas (12th ed.). Prenadamedia Group. 
The Canadian Mental Health Association (CMHA). (2020). The Canadian Mental Health Association (CMHA). https://toronto.cmha.ca Undang-undang Republik Indonesia Nomor 18. (2014). UndangUndang Republik Indonesia Nomor 18 Tahun 2014 Tentang Kesehatan Jiwa.

Van Bortel, T., Basnayake, A., Wurie, F., Jambai, M., Koroma, A. S., Muana, A. T., Hann, K., Eaton, J., Martin, S., \& Nellums, L. B. (2016). Psychosocial effects of an Ebola outbreak at individual, community and international levels. Bulletin of the World Health Organization, 94(3), 210214. https://doi.org/10.2471/BLT.15.1 58543

WHO. (2016). Strategizing national health in the 21st century: A handbook. World Health Organization.

https://www.who.int/publications/ $\mathrm{i} /$ item/strategizing-nationalhealth-in-the-21 st-century-ahandbook

WHO. (2017). Mental Health ATLAS 2017.

https://www.who.int/mental_healt $\mathrm{h} /$ evidence/atlas/mental_health_at las_2017/en/

WHO. (2020). Coronavirus Disease 2019 (Covid-19) Situation Report. https://covid19.who.int/

Xiong, J., Lipsitz, O., Nasri, F., Lui, L. M. W., Gill, H., Phan, L., Chen-Li, D., Iacobucci, M., Ho, R., Majeed, A., \& McIntyre, R. S. (2020). Impact of COVID-19 pandemic on mental health in the general population: A systematic review. Journal of Affective Disorders, 277, 55-64. https://doi.org/10.1016/j.jad.2020. 08.001

Yadav, R. (2021). Psychological Distress in Healthcare Workers During
Covid-19 Pandemic. Journal of Medical Pharmaceutical and Allied Sciences, 10(1), 2644-2652. https://doi.org/10.22270/jmpas.v1 $0 \mathrm{i} 1.1019$

Zhang, Z., Feng, Y., Song, R., Yang, D., \& Duan, X. (2021). Prevalence of psychiatric diagnosis and related psychopathological symptoms among patients with COVID-19 during the second wave of the pandemic. Globalization and Health, 17(1), 44. https://doi.org/10.1186/s12992021-00694-4

Zhou, F., Wang, R.-R., Huang, H.-P., Du, C.-L., Wu, C.-M., Qian, X.-M., Li, W.-L., Wang, J.-L., Jiang, L.-Y., Jiang, H.-J., Yu, W.-J., \& Cheng, K.-B. (2021). A randomized trial in the investigation of anxiety and depression in patients with coronavirus disease 2019 (COVID-19). Annals of Palliative Medicine, 10(2), 2167-2174. https://doi.org/10.21037/apm-21212 